УДК 009

\title{
ИСТОРИЧЕСКИЕ И ПРИРОДНЫЕ ПАМЯТНИКИ ВЕЛИКОЙ КАЗАХСКОЙ ЗЕМЛИ
}

\author{
Маркарьян Владислава Рубеновна \\ ученица 9 «В» класса \\ Научный руководитель: Корницкая Вероника Игоревна \\ учитель английского языка \\ Коммунальное государственное учреждение \\ "Общеобразовательная школа №160"
}

Аннотация: Актуальность выбранной темы обусловлена изучением необычных мест Казахстана, а так же составлением маршрута для экспедиций на святые места казахской земли. Описанные в данной работе места, можно использовать в качестве маршрута для путешествий.

Ключевые слова: Казахстан, природа, Алматы, туризм, памятники.

\section{HISTORICAL AND NATURAL MONUMENTS OF THE GREAT KAZAKH LAND}

\author{
Markaryan Vladislava Rubenovna \\ Scientific adviser: Kornitskaya Veronika Igorevna
}

\begin{abstract}
The relevance of the chosen topic is due to the study of unusual places in Kazakhstan, as well as the preparation of a route for expeditions to the holy places of the Kazakh land. The places described in this paper can be used as a travel route.
\end{abstract}

Key words: Kazakhstan, nature, Almaty, tourism, monuments.

\section{INTRODUCTION}

Cultural heritage is one of the most important reasons for civilized society, which, being a kind of spiritual, moral and material values, requires from one generation to another, to invest great effort and money, not just to pass from one generation to another, but not to lose them. Modern computer technologies, preservation of cultural heritage in the conditions of global processes becomes 
important for each people and leads to loss of identity of the people of the world. Therefore, today the preservation of cultural heritage is relevan for all.In order to develop the culture of Kazakhstan, a number of complex measures were developed, one of which was the development program "Historical and cultural heritage". The purpose of this program was to develop the educational and spiritual areas of culture, to study, preserve and use the cultural heritage of the country, tangible and intangible. Today scientific researches of various spheres of culture are actively carried out on the territory of Kazakhstan. Special attention is paid to archaeology. After all, without knowing the past, it is impossible to know the future and form national unity and self-consciousness of the people. Archeological expeditions are organized, in which samples of historical and cultural monuments are studied and exhibited at various exhibitions and museums. The modern culture of Kazakhstan was formed as a result of close interaction of medieval States, such as the Western Turkic, and then the Turgesh and Karluk khaganates, as well as the States of Karakhanids, Kipchaks. The capitals of these States were located on the territory of modern Kazakhstan, so the Kazakh culture harmoniously synthesized the traditions of farmers and nomads, urban culture and the culture of the steppe. The word "tourist" appeared in English at the beginning of the XIX century and translated from English means: someone who makes a trip for his own pleasure. According to the UN definition, a "tourist" is a person staying in a given area for more than one night and less than a year. Tourism is a relatively young phenomenon, but it has roots that go far back in time. The history of tourism is a temporary periodization of tourism, pursuing the allocation of internally homogeneous stages in its development. With this concept we are faced, almost every day. This can be messages from advertisements on the radio, TV, Internet; conversations of others who have visited any tour; view from the street of the office of a travel company, on the front door of which you can always see ads about "burning" tours. Each of us imagines tourism as an industry, more or less known, because we all went somewhere and spent holidays away from home. International tourism is currently one of the most dynamically developing sectors of foreign economic activity. The steady growth of the impact of tourism on the world economy as a whole and on the economies of individual countries and regions is one of the most significant, permanent and long-term trends that accompany the formation and development of the world economy. The transformation of tourism into a large independent branch of the national economy, whose activities are aimed at meeting the specific needs of the population, is becoming obvious. The diversity of these needs is met not only by 
tourism enterprises, but also by enterprises of other industries, which determines the importance of tourism as one of the factors of multiplicative impact on the development of the economy. Tourism is one of the factors of world integration processes, and tourism business is now becoming a significant sector of the economy. Kazakhstan, possessing unique natural resources and original culture of nomadic people, has a huge unrealized potential for the development of tourism in the international and regional markets. The tourism potential of recreational resources and historical and cultural heritage allows the Republic to integrate harmoniously into the international tourism market and achieve intensive development of tourism in the country. This will ensure sustainable growth of employment and income, stimulate the development of tourism-related industries and increase the inflow of investments into the national economy. The tourism industry in the Republic of Kazakhstan at the state level is recognized as one of the priority sectors of the economy. Thus, in the implementation of the provisions of industrial and innovative development of the country's economy, the leading role belongs to the cluster system, in particular the tourist cluster. Modern trends in the development of this industry are such that tourists who have well studied the most famous resorts in the world, tend to those countries where the tourism sector is just beginning to develop. From this position, the attractiveness of Kazakhstan is growing.

Cultural heritage of Kazakhstan - objects related to the history of religion, culture and life of the peoples of Kazakhstan, included in the legislation of this country on cultural heritage. Some of them are also UNESCO world heritage sites. Almaty region is a region in the South-East of the Republic of Kazakhstan. It was formed on March 10, 1932 as part of the Kazakh USSR, while up to 1992 the spelling Alma-ATA region was adopted. The administrative center of the region was the city of Alma-ATA; in April 2001, the regional center was moved from Alma-ATA to Taldykorgan by the decree of the President of the Republic of Kazakhstan.

Taldykorgan is one of the Kazakh cities located on the great Silk road. Located in the center of Semirechye in the picturesque valley of the Karatal river in the foothills of the Jungar Alatau. The city is located at an altitude of over $650 \mathrm{~m}$ above sea level. The history of the city dates back to the second half of the 19th century: the small village of Gavrilovka, developing, gradually turned into a small town. In 1920, the settlement was renamed Taldy-Kurgan (the Russian equivalent of the native word Taldykorgan, which means "willow mound"in Kazakh). In the 30s 
and early 40s the village was the center of Talda-Kurgan district, and since 1944 it has become a full-fledged city. Already in 1967, the city became the center of the entire region. September 22, 2001 the capital of Almaty region was moved from Almaty to Taldykorgan, and this date was truly the beginning of the revival of the city. Today Taldykorgan is growing and rapidly developing in all spheres. Changing every day, it seems to acquire a new breath.

\section{Kazakhstan - The Land of Wonders}

Kazakhstan is a unique region in the world because of its history, geographical position, and size. Being the world's 9th largest country and located in the centre of Eurasia, it is also the largest landlocked country in the world. These factors have resulted in the country's particular climate and nature, which seem to absorb the brightest examples of the landscape of both continents. In addition, the complicated history of the Kazakh people and the constant interaction of nomadic lifestyle with settled people in South Kazakhstan ancient cities have led to Kazakhstan's unique and authentic culture. These peculiarities have created an opportunity to develop diverse offers in Kazakhstan's travel and tourism industry, to include authentic cultural tourism; nature-based activities, including ecotourism and birdwatching in national parks and protected areas; skiing or trekking in the mountains; water sports, sunbathing, and swimming in the many lakes and rivers of Kazakhstan; and many others. Nature-based tourism. The diversity of Kazakhstan's natural areas has contributed to its rich flora and fauna. The country is a habitat for about 122 mammal species, 500 bird species, and 107 fish species; in addition, over six thousand species of plants grow in the region. In order to preserve such a rich world of plants and wildlife, a network of national parks and nature reserves was established in the country. Recently, these protected areas have become accessible to visitors. The most famous of them among tourists include Aksu Zhabagly Nature Reserve, which is home to snow leopards and other rare animals, and is also known as the "Kingdom of Tulips", as it is believed that tulips originated here, long before they were introduced in Holland; also, Korgalzhyn Nature Reserve is famous for its pink flamingos and other rare species of wildlife and is popular among birdwatchers; Altyn Emel National Park is interesting for its mystery of Singing Dune; and Katon-Karagay National Park is a habitat of marals (red deer), unossified antlers of which are used as a precious medicine. Culture: ethnotourism Kazakhstan's unique culture is a reason why many tourists travel to Kazakhstan. In almost every corner of the republic, a visitor interested in the lives of genuine Kazakh people - their traditions, their rituals, their art, and their culture - will find 
much of interest. This can include museum complexes, ethno villages depicting the traditional lifestyle of Kazakh people, historical sites of medieval cities, and much more. For example, tourists are offered to experience traditional lifestyle of Kazakhs, to try national dishes and to interact with the local people in Shabanbay Bi Village, situated in Kyzylaray Mountains, Central Kazakhstan. Zhambyl Zhabayev museum complex in Almaty region includes a house with a garden, where the poet lived in XIX-XX centuries and a mausoleum. This is a visual representation of not only Zhambyl's life, but also of a whole era in which the poet lived and worked. South Kazakhstan is famous for ancient cities located at the routes of the Great Silk Road with historical monuments and other sites. Ethno-memorial complex Map of Kazakhstan - Atameken, located in Astana, is the largest ethnographic park in Kazakhstan and a unique outdoor museum. Cities and landscapes of the country, as well as mini copies of main attractions and historical sites can be found on the map.

\section{Kazakhstan sights and architectural monuments:}

\section{Aisha-Bibi}

Aisha Bibi Mausoleum is the only monument in the whole Central Asia faced completely with fretted terracotta. It is included into the UNESCO list of the most valuable historical architectural monuments of the mankind.

\section{Babdja Khatun}

Mausoleum is famous for its 16-rib umbrella shaped dome. There is no second architectural monument of this kind in the Central Asia. The figured brickwork decorates the walls of the Mausoleum.

\section{Otrar}

About $150 \mathrm{~km}$ North-West of Chimkent lie the ruins of Otrar the town that brought Chengiz Khan to Central Asia when its Governor murdered Great Khan's Merchants in 13th century.

\section{Baikonur Cosmodrome}

Baikonur Cosmodrome became historical for the whole planet, here the faith of our civilization was decided and the countdown of the new era of living for people started.

\section{Kazakhstan natural sites - Where to go:}

Charyn canyon. Charyn canyon is called "The little brother of the American Grand Canyon", Charyn canyon is carved by the rapidly flowing Charyn river in to a flat and barren steppe $175 \mathrm{~km}$ East of Almaty. The passage of time has weathered this in to all sorts of weird, wonderful and colorful rock formations. Charyn Canyon is situated in the territory of the Charyn National Park. The National park was 
founded on 23 February 2004. The Park territory is inhabited with a great number of rare and endangered animal species entered in the Red Book. In Sarytogai natural boundary of the Park territory, there are protected forests are growing with one of the most unique trees - Sogdian ash existed as far back as the Palaeogene epoch. The aspen grove is unique, the second analogue grove is found in North America. The aspen grove, a monument of nature is especially protected under aegis of UNESCO. Its age is about 5 million years. But the most famous area of unique interest in the Park is certainly Charyn Canyon. This picturesque indigenous locality impresses with its heavenly landscapes The Canyon depth is $200 \mathrm{~m}$. The height of the bluff mountains of the Canyon reaches $150-300 \mathrm{~m}$. The Canyon itself represents a monument of nature formed with sedimentary rocks aged more then 12 million years. The landscapes are virtually miraculous there.

Altyn-Emel (National park). Situated $150 \mathrm{~km}$ from Almaty in South-Eastern Kazakhstan in Dzhungar mountain region. This national park covers an area of 600 thousand hectares. The area contains about 190 archaeological monuments of burial mounds and settlements of Bronze Age. It has a rich fauna including snow leopard, wolf, fox, steppe cat and many others.

Tamgaly-Tas. Tamgaly Tas in Kazakhstan is famous for its rock carvings. These picturesque rocks attract many tourists. It was place, where incredibly beautiful images of Buddha and Burhans (Bodhisattvas) were found. The cave drawings are accompanied by exquisite Tibetan inscriptions. The unique style of the images is achieved by fine art of stone carving and fine contour lines.

Borovoe. Borovoe or Burabai pine forest is good at any time, in every weather. In winter the pine forest is covered with white snow, in summer - a light wind blows up the aromatic resinous waves, in autumn - the forest smells the peculiar air, a mixture of wet pine rind with mushrooms and herbs. Borovoe is a resort, known far beyond Kazakhstan, rich in health centers, which are involved in climalology treatment and treatment by cumus (horse's milk). Kazakhstani Switzerland is the second name given to Burabai, Kokshetau region, which is in the Northern Kazakhstan. Amidst the yellow scorched unending steppe you just encounter the green wall of forest. "Bura " in Kazakh stands for camel. There is an old legend about prophetic camel, which used to live in Burabai neighborhood. Honey herbage didn't blunt his instinct for an instant - it was he who was the first to anticipate the people's awful lot and then he turned to a tulpar (horse) and flew to the peak of Kokshetau thus averting people from the coming misfortune. Burabai lacks any monuments of material culture. But its legends, nature do impress as some grand 
castles and palaces. The nature kindly gifted Burabai with valuables from its mineral depository. They are as following: Okzhetpes - the most beautiful crag (Kasakhs used to call it "one can't reach it by an arrow"), Zhumbaktas (puzzlestone), in the Burabai bay resembling either a mysterious sphinx with frozen fearless traits, or a thoughtful, young man with hair flying; vast stony sculptures, resembling a camel, a dog, a cow.

Big Almaty lake is a picturesque pond located in the spurs of the TRANS-ili Alatau, $15 \mathrm{~km}$ South of the city of Alma-ATA. The reason for the formation of the lake was a major earthquake that caused the collapse of the mountain slopes and the appearance of an embankment dam in the river bed. Big Almaty lake lies in a deep tectonic depression and is surrounded by steep rocky shores. Three mountain peaks rise above the water surface - Sovetov, Ozerny and Turist, the height of which ranges from 3900 to 4300 meters.

\section{Historical and cultural monuments of Almaty region}

\section{and prospects of tourist routes}

Monuments of history and culture of Kazakhstan of Republican significance separate constructions, buildings and constructions with historically developed territories of the specified constructions, buildings and constructions, memorial houses, quarters, necropolises, mausoleums and separate burials, works of monumental art, stone sculptures, rock images, the archaeological monuments included in the State list of monuments of history and culture of Kazakhstan and being potential objects of restoration representing historical, scientific, architectural, art and memorial value and having special value for history and culture of all country. Lists of historical and cultural monuments of national importance are approved By the government of Kazakhstan on the proposal of the authorized body for the protection and use of historical and cultural heritage. Tourism is one of the strategic sectors of the economy of many countries of the world, which has great potential for growth and serious chances for development in the future. Kazakhstan in General and Almaty region in particular have real opportunities to become a fullfledged tourist destination with modern and developed infrastructure.

About the tourist potential of Zhetysu, about the most amazing routes that exist for travelers in Almaty region and about promising projects in tourism, I tried to write in detail in my work. Currently, the government of the Republic of Kazakhstan pays quite serious attention to the development of the tourism industry in the country. The tourism industry provides opportunities to create direct jobs and attract the flow of foreign currency. Tourism has a broad and direct impact on the 
social development of the country, contributes to the development of labor skills and professional growth. With the active assistance of the state in development of tourist infrastructure opportunities for development of small and medium-sized businesses and entrepreneurship in General, which has a positive effect on the economic development of not only the region but the country as a whole. Due to the diversity of natural landscapes, Almaty region is one of the richest regions in Kazakhstan in terms of tourist opportunities. Almaty region was formed on March 10, 1932, in 1997 merged with Taldykorgan region, as a result of its territory it occupies the 5th place in the country-224 thousand square kilometers, which is equal to the territories of such European countries as Greece and Hungary combined.

The region occupies the entire South-East of the Republic, the territory called Zhetysu (Semirechye). Zhetysu is the pearl of Kazakhstan and means seven rivers flowing on this land and flowing into lake Balkhash. This is a beautiful and unique region. Amazing secrets are kept by the land known under the poetic name Zhetysu, where in the distant past the paths and historical destinies of many tribes and peoples crossed. In no region of the Republic is there such a cluster of Saka, Turkic mounds, rock paintings. Semirechye is rich in monuments of history, culture, nature, unique sports facilities. Charyn canyon, rock paintings Tamgaly TAS, monuments of Eastern religion, many mounds and settlements, relict groves, picturesque landscapes of Jungar and Alatau, high-mountain resort "Ak-Bulak", sports and recreation complex "Tabagan" are of interest for world tourism. Together with the Kazakhstan Association of inbound and domestic tourism "KITA "for the long term developed and approved by the decision of the regional maslikhat" Master plan of tourism development of Almaty region", which gives a cluster direction for the development of tourism in accordance with the concept of development of the tourism industry of the Republic of Kazakhstan until 2020. The master plan is developed on the basis of a comprehensive analysis of the current state of the tourism industry in the region, taking into account international experience and is a plan for the development of tourism in the region. It is planned to form 5 clusters in the region: Talgar-Issyk, Kapchagai, Karadala, Rayymbek, Alakol-Zhetysu and East Balkhash. The main purpose of the document was to increase the competitiveness of our tourism product, create favorable conditions for doing business, and develop infrastructure. Special attention in the master plan is paid to the creation of tourism infrastructure on the shores of lakes Balkhash and Alakol in order to develop health and beach recreation. State support of tourism is a 
necessary condition for sustainable development of the industry. Thus, in 20142015, 93.8 kilometers of power lines were brought to the recreation areas of Akshi village within the framework of the "business Road map - 2020" program. Almaty region has a serious potential for the development of all-season domestic and inbound tourism. This is a huge territory of contrasts, where almost next to large megacities and cities are large areas of untouched nature civilization. From the reviews of foreign tourists who visited Almaty region, this is one of the few corners of the earth where dawn can be found in the steppe, noon in the forest, sunset-on a mountain pass. The surroundings of Almaty have a very diverse tourist and recreational resource. The uniqueness of the region is due to the fact that here you can fully develop almost all types of tourism. For example, ecological tourism, balneological, cultural and historical, sports and extreme, adventure, family. Currently, Almaty region has 1519 historical and cultural monuments, of which 262 architectural monuments, 1250 archaeological, 7 natural, 9 national and world value. In addition to the presence of unique natural landscapes, archaeological and architectural monuments, the region is part of the great silk road, which, of course, can seriously affect the increase in the level of interest among foreign tourists to this region. Currently, the Republic of Kazakhstan is involved in a very important and strategic project - the construction of the transport corridor Western Europe Western China. About $301 \mathrm{~km}$ of the Western Europe - Western China transport corridor will run through the territory of Almaty region. It is safe to say that this project will provide a real opportunity for the development of caravan tourism in the region. In addition to all of the above, Kazakhstan as a whole is famous for its hospitality and very respectful attitude to foreign guests and tourists. And this is only a small part of the huge number of positive qualities that contribute to the development of tourism in the region. Kazakhstan Association of inbound and domestic tourism together with the Department of tourism of Almaty region, foreign consultants and specialists offers a modern vision of tourism development in Almaty region. Taking into account the extensive experience in the field of domestic and inbound tourism, we offer a 24 number of comprehensive measures aimed mainly at the development of tourism in the Almaty region. The need to change the situation and will be in the coming years, the main goal of the implementation of the master plan. It is a voluntary Association and cohesion between the tourist subjects of Almaty region. This is a clear reference point for the future, which offers valuable directions for the development of tourism and the economy of the Almaty region as a whole. 


\section{Historical places of the sacred Kazakh land (Taldykorgan)}

Taldykorgan is a city located in Almaty region. It has the status of the regional center of the Republic of Kazakhstan. The name of the town translates as "hill surrounded by willows". In Taldykorgan there are many parks, museums, theaters and a large number of other attractions. In this list only some of them:

1) Historical Museum named by M. Tynyshbayeva. The Museum named by M. Tynyshbayeva was opened on March 1, 1974. Historical and local history Museum named by M. Tynyshbayeva is the only Museum in the region that collects and preserves the history of Zhetysu region. The Museum houses 27454 exhibits. The size of the hall of exhibits - 1091 sq. m.

2) The Museum Of Zhambyl Zhabaev. Zhambyl Zhabayev literary and memorial Museum is located in Zhambyl district of Almaty region. The Museum complex is located $70 \mathrm{~km}$ from Almaty, in the village with the symbolic name "Zhambyl Museum". The complex includes the poet's house, garage and garden,one administrative building,as well as the mausoleum of Zhabayev.

3) Bayanzhurek Petroglyphs. As a major monument of rock art Bayanzhurek known since the 1980s. The Monument is representative as a major location of petroglyphs of the Bronze Age and the Turkic middle ages.

4) Petroglyphs of Eshkiolmes. The archaeological complex of Eshkiolmes consists of more than 250 monuments of different types-settlements, burial grounds, altars and petroglyphs Dating from the middle of the II Millennium BC to the beginning of the XX century. The High concentration of monuments in a limited area testifies to the great economic and cultural importance of this area of Semirechye.

5) Temple of the Archangel Gabriel. The temple is a religious building intended for worship and religious rites.

6) Evangelic-Lutheran Parish. Church, Christian temple-a religious building designed for the Assembly of Christians, worship and religious rites. The main temple of the city or monastery is usually called the Cathedral.

7) Mosque Nur. Ak Mosque. The mosque is a Muslim prayer architectural structure.

8) "Monument to the three brothers." In the center of Taldykorgan in 2006 in honor of the great ancestors, in whose honor flowers were laid to their descendants. The sculptural composition of the monument "Ush ATA" depicts three historicaligures: Eskeldy bi, Balpyk bi and Kablisa Zhyrau, who made a significant contribution to the defeat of the thick troops of the Dzungars. The area of Zhetysu is 
rich in its history, which until our time and to this day is studied by great scientists, poets, singers in their works . Priceless monuments of the history of Zhetysu region are the rock paintings, stone images of the old burial mounds and the ruins of old cities. In 2009, the Almaty regional center for the protection of historical and cultural heritage was established in our region in order to study the history, cultural heritage of the region, as well as to take under the protection of historical and cultural monuments. The creation of the center opened the possibility of the progress of works carried out within the framework of the program "Cultural heritage" financed by the Republican and regional budgets.

\section{CONCLUSION}

Kazakh cultural heritage - is the part of global cultural heritage. Kazakhstan is in need of support to maintain his history and culture, to create his own tourism industry for the purpose to make this heritage free for all mankind. Almaty has a special tourist potential. Every year, many tourists from Europe, Asia, including Japan, come to see historical and cultural monuments. Our historical monuments preserved in this Treasury, mountains, lakes, archaeological grids, themes, many mysteries of interest to tourists. It can be concluded that Kazakhstan is a region with a unique colorful landscape and climatic conditions. The natural diversity and diversity of cultures confirms the status of a tourist attractive region. There are all conditions for the development of a tourist product characterized by dynamism and diversity. Kazakhstan is the territory of ancient civilizations. From time immemorial, the inhabitants of the Kazakh land created a bright and original culture. Today Kazakhstan is famous for its historical monuments-barrows, ruins of ancient settlements, fortresses, mausoleums and ancient settlements. The Republic of Kazakhstan provides almost all existing types of tourism - educational, entertainment, ethnic, environmental, health, children's, sports, hunting, equestrian, adventure. More than 700 travel routes are offered for tourists throughout the territory of Kazakhstan. During my research I learned quite a lot about my country and can draw the following conclusions:

1) There are a lot of places in Kazakhstan, amazing in their beauty, full of secrets and legends. This applies to any part of the country. In the South of Almaty with stunning mountains, in the West the Caspian sea and desert, just cosmic landscapes, in the East the Altai mountains. And the mountains Bayanaul, BektauATA, lake Balkhash, Zaisan, Alakol, the Aral sea with its terrible disaster. And these are only natural attractions. But there are still historical monuments, there are modern cities that we can be proud of, there is Baikonur-the cradle of world 
space! Our camp has every chance to be a place where tourists come from all over the world!

2) Since I was studying the amazing places created by nature, I was faced with another problem that is relevant for most of Kazakhstan. This is an environmental problem. The tragedy of the Aral sea has long been known to everyone, and lake Balkhash is in a difficult situation. We see how our Irtysh shallows from year to year, how the quality of river water deteriorates. And in the Bayanaul mountains, previously completely green, now you can see places where there is no living tree around, but only dried twisted trunks and branches. It's like footage from a movie about some universal catastrophe.

\section{References}

1. "Мәдени Мұра" - Культурное наследие Казахстана

2. Ердавлетов С.Р. География туризма: история, теория, методы, практика. - Алматы, 2000.

3. Ердавлетов С.Р. История туризма. Развитие и научное изучения. Алматы, 2003.

4. Квартальное В. А. Туризм: теория и практика: Избранные труды: В 5ти т. - М.: Финансы и статистика, 1998.

5. Официальный сайт Министерства РК По туризму и спорту http://www.mts.gov.kz/

6. Муратбек В. Памятники истории Казахстана. Астана: Меруерт, 2005.

7. Шаповал Г.Ф. История туризма. - Минск, 1999. - 303 с.

8. Алма-Ата. Энциклопедия / Гл. ред. Козыбаев М. К. - Алма-Ата: Гл. ред. Казахской советской энциклопедии, 1983. - С. 159. - 608 с.

9. Tourism of Kazakhstan. Statistical collection of the Agency of Statistics of The Republic of Kazakhstan, 2007-2011, Astana, 2012.

10. Concept of tourism development in the Republic of Kazakhstan to Provision of Government of the Republic of Kazakhstan from February, 28, 2013, № 192.

11. nomadic.kz

12."Kazakhstan to develop its tourism industry. Environment. Tengrinews.kz". En.tengrinews.kz. 18 June 2014. Retrieved 18 November 2015.

13. Гилек Ю.Н. Туристические маршруты центрального Казахстана. Караганды: Издательство КарГУ, 2005.

14. http://www.3d-maps.kz/ru 